\title{
Demokratyczne państwo prawne i podstawy ustroju demokratycznego w dyskursie Sejmu X kadencji
}

PAWEŁ FIKTUs - wykładowca Wyższej Szkoły Prawa we Wrocławiu. Współredaktor takich opracowań, jak: Śladami Jerzego Giedroycia (Kraków 20I4) i Samorząd w myśli polityczej i prawnej, Wrocław 2017 (wspólnie z Maciejem Marszałem) oraz Rodzinna Europa. Europejska myśl polityczno-prawna u progu XXI wieku, Wrocław 2015 (wspólnie z Maciejem Marszałem i Henrykiem Malewskim). Autor publikacji z zakresu historii prawa, historii doktryn polityczno-prawnych oraz prawa administracyjnego. 
Spory o Rzeczpospolita. Przeglad wybranych dyskusji politycznych $i$ ustrojowych w ostatnim stuleciu, red. P. Gofron, A. Matuła, A. Paderewska, Kraków 2020, s. $62-84$.

W

ybory czerwcowe przeprowadzone w 1989 roku, dokonały nie tylko poważnej przemiany na polskiej scenie ustrojowej, ale także wyborny wówczas Sejm X kadencji (zwany jako kontraktowy) jeszcze w 1989 roku doprowadził do przyjęcia tzw. noweli grudniowej, którą dokonano radykalnej zmiany Konstytucji z dnia 22 lipca 1952 roku. W prowadzono wówczas zapis, że „Polska jest demokratycznym państwem prawnym, urzeczywistniającym zasady sprawiedliwości społecznej”, a w art. 2. 1. nowy zapis: „W Rzeczypospolitej Polskiej władza zwierzchnia należy do Narodu”".

Przedmiotem niniejszej publikacji jest przybliżenie, w jaki sposób doszło do wprowadzenia tejże zasady do polskiego porządku prawnego, dodając przy tym, że zasada, jak się potem okazało, fundamentalna, stała się fundamentem najważniejszych zmian, jakie zachodziły wówczas w państwie. Wprowadzając zasadę demokratycznego państwa prawnego, usunięto z konstytucyjnych zapisów tezy: Polska Rzeczpospolita Ludowa jest państwem socjalistycznym; w Polskiej Rzeczpospolitej Ludowej władza należy do ludu pracującego miast i wsi.

Niemniej Sejm X kadencji rozpoczął swe prace, bazując na Konstytucji z I952 roku. Mimo jej nowelizacji kwietniowej w I989 roku², był to akt prawy w wielu punktach odnoszący się do ustroju socjalistycznego. Przemiany polityczno-społeczne, jakie wówczas zaszły w Polsce,

I Ustawa z dnia 29 grudnia I989 r. o zmianie Konstytucji Polskiej Rzeczypospolitej Ludowej (Dz. U. Nr 75, poz. 444).

2 Dz. U.z I989 $\mathrm{Nr}$ i9, poz. гог. 
nijak nie pasowały do jej postanowień. Przypomnieć należy chociażby obrady tzw. Okragłego Stołu, wspomniane wybory czerwcowe, wprowadzenie urzędu prezydenta (rozdział 3a Konstytucji) czy też wybór Tadeusza Mazowieckiego na urząd premiera RP oraz powołanie w dniu I2 września I989 roku rządu, składającego się z członków Solidarności oraz PZPR, Zjednoczonego Stronnictwa Ludowego i Stronnictwa Demokratycznego.

\section{Zasada demokratycznego państwa prawnego i jej reguły w projektach poselskich}

Już na wstępie należy zasygnalizować, że zmiany dotyczące wprowadzenia zasady demokratycznego państwa prawnego pochodziły zarówno ze strony posłów Polskiej Zjednoczonej Partii Robotniczej (dalej PZPR), jak i ze strony posłów wywodzących się ze środowiska solidarnościowego i skupionych wokół Obywatelskiego Klubu Poselskiego (dalej: OKP). Podczas procesu legislacyjnego przedstawiono kilka poselskich propozycji, które odnosiły się do zmian ustrojowych oraz do wprowadzenia do systemu prawnego zasady demokratycznego państwa prawnego. Pierwszym dokumentem, jaki został złożony do ,laski marszałkowej” był druk nr 25 z dnia 6 września 1989 roku zawierający poselski projekt o zmianie nazwy Państwa Polskiego i symboli narodowych ${ }^{3}$. W uzasadnieniu wskazano, że w nazwie „Polska Rzeczpospolita

3 Druk został wniesiony przez posłów Zdzisława Barańskiego, Alfreda Bielewicza, Stefana Bielińskiego, Tadeusza Bienia, Janusza Błaszczyka, Andrzeja Bondarewskiego, Krzysztofa Czeryskiego, Kazimierza Czerwińskiego, Teresę Dobielińską-Eliszewską, Annę Dynowską, Tadeusza Dziubę, Mirosława Grabarkiewicza, Jana Janowskiego, Jana Knoppka, Andrzeja Konopkę, Jana Kościelniaka, Lesława Lecha, Kazimierza Modzelewskiego, Mirosłąwa Nowakowskiego, Bohdana Osińskiego, Mariana Popisa, Zbigniewa Rudnickiego, Jerzego Ruseckiego, Jerzego Ślezaka, Stanisława Suchodolskiego, Jana Świtka oraz Kazimierza Ujazdowskiego. 
Ludowa” jest błąd lingwistyczny, gdyż termin „ludowy” odnosi się tylko i wyłącznie do ludności wiejskiej (lub też włościańskiej). Z kolei zestawienie dwóch terminów w zwrocie ,,demokracja ludowa” miało za zadanie podkreślić, że Polska jest krajem ludzi pracujących, czyli robotników, chłopów i inteligencji pracującej z pominięciem ludzi żyjących z cudzej pracy (spekulantów, pasożytów czy też wyzyskiwaczy). Ponadto w pierwotnym uzasadnieniu stwierdzono, że

przywracając zatem państwu polskiemu nazwę ,,Rzeczpospolita Polska” akcentujemy nie tylko, że obecnie wszyscy obywatele mają równe prawa, ale również odcinamy się od niesławnych tradycji minionego okresu

Warto przy tym dodać, że pismem z dnia 30 listopada 1989 roku, zmieniono uzasadnienie do planowanej zmiany ustawy zasadniczej. Akcentowano przy tym językową analizę przymiotnika „ludowy”, aczkolwiek uznano także, iż

mając na względzie kierunek rozwoju polskiej państwowości wystarczy się posłużyć terminem ,rzeczpospolita”, aby istota społeczna państwa była w nazwie określona z dostateczną wyrazistością̧5.

Kolejny etap dotyczący wprowadzenia do polskiego porządku prawnego zasady demokratycznego państwa prawnego związany z projektem poselskim dotyczącym zmiany konstytucji, jaki został przedstawiony również w dniu 6 września 1989 roku, w druku nr $26^{6}$. Główny punkt tej zmiany dotyczył wprowadzenia zwrotu, że władza należy do Narodu, aczkolwiek proponowany art. I Konstytucji miał brzmieć:

4 Karta [dalej: k.] 2 uzasadnienia druku nr 25 z dnia 6 września I989 roku.

5 K. 2 uzasadnienia z dnia 30 listopada 1989 roku.

6 Autorami tej zmiany byli posłowie: Zdzisław Barański, Alfred Bielewicz, Stefan bieliński, Janusz Błaszczyk, Andrzej Bondarewski, Krzysztof Czereyski, Kazimierz Czerwiński, Teresa Dobielińska-Eliszewska, Tadeusz Dziuba, Mirosława Grabarkiewicz, Jan Janowski, Jan Knoppek, Andrzej Konopka, Lesław Lech, Mirosław Nowakowski, Bohdan Osiński, Marian Popis, Jerzy Rusecki, Jerzy Ślęzak, Stanisław Suchodolski oraz Kazimierz Ujazdowski. 
„Władza zwierzchnia w Polskiej Rzeczypospolitej Ludowej należy do Narodu”. Proponowana zmiana miała dotyczyć wprowadzenia zwrotu „,naród” z jednoczesnym pozostawieniem nazwy państwa7. Wskazano przy tym, że w doktrynie politycznej przyjęło się, że suwerenem jest Naród, a nie klasy czy też grupy społeczne. Z kolei państwo polskie jest wspólnym dobrem wszystkich obywateli bez stosowania jakiegokolwiek cenzusu (płci, zawodu, wykształcenia, rasy czy też wyznania) ${ }^{8}$.

Z kolei inna zmiana, aczkolwiek opracowana wcześniej, bo w dniu 23 sierpnia 1989 roku, została zaprezentowana w druku nr 27. W tym przypadku zmiana dotyczyła wykreślenia z zapisów konstytucyjnych osławionego zdania wprowadzonego nowelizacją w 1976 roku, a związanego z przewodnia rolą PZPR: ,Przewodnią siłą społeczeństwa w budowie socjalizmu jest Polska Zjednoczona Partia Robotnicza”. Wskazano przy tym, iż ów zapis został wprowadzony w dobie dominacji PZPR oraz że nawiązywał do ówczesnej polityki legislacyjnej, jaka obowiązywała w innych państwach socjalistycznych. Jednakże ówczesna sytuacja polityczna wymusza konieczność zmian. Ponadto wnioskodawcy podali, że

o roli jakiejkolwiek partii powinien decydować nie zapis konstytucyjny, lecz program, sposób działania oraz akceptacja społeczeństwa realizowana poprzez wolny demokratyczny wybór jej przedstawicieli do Sejmu i władz państwowych ${ }^{10}$.

7 Pozostałe zmiany miały dotyczyć: zmian w obrębie akcentowanej formy własności, ochrony własności, wywłaszczenia, możliwości pozbawienia obywatela wolności tylko i wyłącznie przez sąd czy też wykreślenia zapisów dotyczących tajemnicy państwowej.

8 K. 2 uzasadnienia druku nr 26 z dnia 6 września I 989 roku.

9 Autorami poselskiego druku nr $17 \mathrm{z}$ dnia 23 sierpnia 1989 roku, byli: Józef Bogusz, Jerzy Barnicki, Mieczysław Brudniak, Lucjan Chojecki, Marian Janusz Czerwiński, Ryszard Dyrak, Krystyna Ejsmont, Edward Horoszkiewicz, Edmund Jagiełło, Henryk Komar, Czesław Kosiński, Piotr Lenz oraz Kazimierz Woźniak.

Io K. I uzasadnienia druku $\mathrm{nr} 27 \mathrm{z}$ dnia 23 sierpnia 1989 roku. 
Aczkolwiek wskazany projekt zmian został modyfikowany na podstawie poselskiej inicjatywy zawartej w druku nr 27 A z dnia 7 września I989 $\mathrm{roku}^{\mathrm{II}}$. Zaprezentowana wówczas zmiana w art. 3 Konstytucji miała jeszcze bardziej usankcjonować system wielopartyjny. Przedstawione zmiany miały dotyczyć wprowadzenia czterech zasad:

I. swoboda tworzenia partii politycznych, ale pod warunkiem określenia celów i form ich działalności w zgodzie z demokratycznymi podstawami ustroju określonymi w konstytucji;

2. dobrowolność zrzeszania się obywateli w partiach politycznych;

3. pluralizm polityczny;

4. przyznanie Trybunałowi Konstytucyjnemu możliwości orzekania odnośnie do rejestracji, jak i delegalizacji partii politycznej ${ }^{\mathrm{I} 2}$.

Również zmianie miała ulec rola partii, która miała polegać na tym, że partia polityczna miała pełnić rolę pośrednika pomiędzy wolą ludu (suwerena) a kształtowaniem polityki państwa. Ponadto przewidywano uchwalenie odrębnej ustawy regulującej funkcjonowanie partii, a tym samym zakreślenie w ustawie zasadniczej jedynie wskazanych powyżej czterech punktów ${ }^{13}$.

W podobnym tonie był utrzymany kolejny projekt dotyczący zmian w Konstytucji z 1952 roku, zakładający zmiany dotyczące funkcjonowania partii politycznych. Przedstawiony w druku nr 35 projekt zmian zakładał, że Polska Rzeczpospolita Ludowa zapewni swobodę $\mathrm{w}$ tworzeniu i równoprawne warunki działania partii politycznych

I I Projekt z dnia 7 września I989 roku, zawarty w druku nr 27 A został opracowany przez: Tadeusza Badacha, Jerzego Bartnickiego, Józefa Bogusza, Adama Brodeckiego, Mieczysława Brudniaka, Irenę Chojnacką, Zdzisława Czarnobilskiego, Mieczysława Czerniawskiego, Leszka Czerwińskiego, Mariana Janusza Czerwińskiego, Krystynę Ejsmont, Stefana Gębickiego, Edwarda Horoszkiewicza, Zbigniewa Kawałko, Henryka Komara, Piotra Lenza, Ryszarda Pidka, Izabellę Sierakowską, Wandę Sokołowską, Janusza Szymańskiego, Janusza Trzcińskiego, Waldemara Tokarza oraz Andrzeja Wieczorkiewicza.

I 2 K. 3 uzasadnienia druku nr $27 \mathrm{~A} \mathrm{z}$ dnia 7 września I989 roku.

I 3 K. 3 uzasadnienia druku nr $27 \mathrm{~A}$ z dnia 7 września 1989 roku. 
jak też, że szczegółowe zasady tworzenia i warunki działania partii politycznych określają ustawy ${ }^{\mathrm{T}}$. W projekcie nadal utrzymano nazwę państwa „,Polska Rzeczpospolita Ludowa”, aczkolwiek w tym przypadku w uzasadnieniu przedstawiono jeszcze inny, ciekawy postulat, a dotyczył on potrzeby przyjęcia nowej Konstytucji ${ }^{15}$.

Do zmian dotyczących partii politycznych odwoływano się również w poselskim projekcie zawartym w druku nr 64 z dnia I 6 października $1989 \mathrm{roku}^{16}$. W tym przypadku proponowano, co już zostało zasygnalizowane wcześniej, wprowadzenie regulacji, w myśl której Trybunał Konstytucyjny prowadzi rejestr partii politycznych oraz orzeka o dokonaniu wpisu oraz o delegalizacji partii. Należy przy tym dodać, że w dniu I6 października 1989 roku, ta sama grupa posłów wniosła druki nr 63 A i $64 \mathrm{~A}$, nieznacznie modyfikujące wskazany powyżej projekt.

Kolejny punkt zmian zawarty w poselskim projekcie - druku nr 80 z dnia I7 października I989 roku, dotyczył regulacji prawnych odnoszących się do zasad własności, pozycji Sejmu wobec rad narodowych, jak i prokuratury. W tym przypadku, nie wnosząc propozycji odnośnie zmiany nazwy państwa, zaproponowano, że

Polska Rzeczpospolita Ludowa uznaje i ochrania na podstawie obowiązujących ustaw własność indywidualną. Wywłaszczenie jest dopuszczalne wyłącznie

I4 Druk nr 35 z dnia I 3 września I989 roku. Projekt został wniesiony przez Zdzisława Barańskiego, Tadeusza Bienia, Janusza Błaszczyka, Andrzeja Bondarewskiego, Teresę Dobielińską-Eliszewską, Annę Dynowską, Tadeusza Dziubę, Jana Knoppka, Andrzeja Konopkę, Lesława Lecha, Kazimierza Modzelewskiego, Mirosława Nowakowskiego, Bohdana Osińkiego, Mariana Popisa, Jerzego Ślęzaka, Stanisława Suchodolskiego oraz Jana Świtka.

I 5 K. 3 druku nr 35 .

I 6 Druk nr 64 z dnia I6 października I989 roku. Autorami projektu byli: Szczepan Balicki, Krzysztof Bielecki, Jan Błachnio, Eugeniusz Czykwin, Ryszard Gajewski, Ziemowit Gawski, Jerzy Hopfer, Wojciech Janicki, Urszula Jarosz, Kazimierz Jaworski, Jacek Krzekotowski, Tadeusz Marchlik, Tadeusz Nowacki, Wojciech Polak, Stanisław Rogowski, Józef Starczynowski, Józef Wójcik, Ryszard Zieliński oraz Bonawentura Ziemba. 
za odszkodowaniem w wysokości wynikającej z przepisów ogólnie obowiązujących ${ }^{17}$.

Wskazany powyżej druk został nieznacznie zmodyfikowany, przez tą samą grupę posłów, na podstawie druku nr 80A z dnia 29 listopada I989 roku.

Jednakże niezależnie od przedstawionych powyżej zmian, kluczową rolę $\mathrm{w}$ procesie przemian demokratycznych odegrały nie tylko poselskie inicjatywy, ale także powołana sejmowa Komisja Konstytucyjna i poczynione przez nią ustalenia ${ }^{18}$. Komisja Konstytucyjna została powołana na podstawie wniosku Konwentu Seniorów z dnia 29 listopada 1989 roku, przedstawionego w druku nr I03. Aczkolwiek zakres przedmiotowy Komisji, w świetle wskazanego wniosku, miała mieć szeroki zakres, gdyż dotyczyła nie nowelizacji istniejącej Konstytucji z 1952 roku, ale ,w celu przygotowania Konstytucji Państwa Polskiego" ${ }^{19}$. W jej skład mieli wchodzić przedstawiciele, w liczbie 44 posłów, z najważniejszych ugrupowań politycznych zasiadających wówczas w sejmowych ławach (zarówno OKP, jak i PZPR) ${ }^{20}$.

I7 Druk nr 64 z dnia I 6 października I989 roku.

I 8 Komisja Konstytucyjna została powołana na podstawie uchwały Sejmu PRL z dnia 7 grudnia 1989 roku, przyjętej podczas I 5 posiedzenia Sejmu PRL na podstawie druku nr ı03. W tym puncie należy dodać, że powołanie Komisji konstytucyjnej nie odbyła się bez uwag krytycznych. Wskazać należy na głos posła Stanisława Tomkiewicza, który wskazał, że nie wszystkie ugrupowania polityczne są należycie reprezentowane w Sejmie jak też, mimo iż Komisja odzwierciedlała najważniejsze siły polityczne, to wyraził obawy, aby sprostała swemu powołaniu - zob. sprawozdanie stenograficzne z dnia 7 grudnia I989 roku, z I 5 posiedzenia Sejmu PRL, łam [dalej: ł.] I 2-I4. Z kolei poseł Józef Beszta-Borowski zaproponował, by głosowanie nad powołaniem Komisji odbyło się za miesiąc - co zostało przez Sejm odrzucone - ł. I4-I 5 .

I9 Druk nr I03 z dnia 29 listopada I 989 roku.

20 W jej skład, w świetle, przedstawionej propozycji, mieli wchodzić: Maciej Bednarkiewicz (OKP), Stefan Bieliński (SD), Ryszard Bugaj (OKP), Włodzimierz Cimoszewicz (PZPR), Jan Czaja (PSL - Odrodzenie), Stefania 
Przedstawiony przez Przewodniczącego Komisji - prof. Janusza Trzcińskiego, wrocławskiego konstytucjonalisty (PZPR), w praktyce odnosił się do wcześniej proponowanych zmian. Przede wszystkim zmieniono nazwę aktu ustawy zasadniczej, wprowadzając: ,Konstytucja Rzeczypospolitej Polskiej”. Jednocześnie z całego aktu został wykreślony przymiotnik ,,ludowa”, pozostawiając przy nazwie „Rzeczypospolita Polska”. Wskazano przy tym, że ,projekt przywraca tradycyjną, historyczną nazwę państwa Polskiego, rezygnując tym samym z dotychczasowej formy uzewnętrznienia klasowego kształtu państwowości” ${ }^{21}$. W uzasadnieniu po raz kolejny podkreślono, że koniecznym jest uchwalenie nowej Konstytucji, aczkolwiek na obecną chwilę koniecznym jest wprowadzenie zmian w obrębie istniejącej ustawy zasadniczej. Mimo iż zmiany dotyczyły jedynie kilkunastu przepisów, to trzeba zauważyć, że po pierwsze sankcjonują zmiany, jakie zaszły w Polsce, a po drugie torują drogę dalszym przemianom „zwłaszcza w sferze nowego, rynkowego ładu gospodarczego"22. Zmia-

Czupała-Hołoga (PZKS), Janusz Dobrosz (PSL - Odrodzenie), Krzysztof Dowgiałło (OKP), Marek Dziubek (OKP), Tadeusz Fiszbach (PZPR), Bronisław Geremek (OKP), Wojciech Gryczewski (PSL - Odrodzenie), Waldemar Grzywacz (PZPR), Ryszard Helak (OKP), Kazimierz Jaworski (PAX), Dorota Kempka (PZPR), Andrzej Kern (OKP), Tadeusz Kijonka (PZPR), Teresa Liszcz (PSL - Odrodzenie), Paweł Łączkowski (OKP), Romualda Matusiak (PZPR), Adam Michnik (OKP), Włodzimierz Mokry (OKP), Józef Oleksy (PXZPR), Marian Orzechowski (PZPR), Walerian Pańko (OKP), Lech Paprzycki (PSL - Odrodzenie), Jacek Piechota (PZPR), Antoni Pieniążek (PZPR), Emilia Pogonowska - Jucha (PSL - Odrodzenie), Stanisław Rogowski (UChS), Jan rokita (OKP), Zbigniew Rudnicki (SD), Jerzy Rusecki (SD), Grażyna Staniszewska (OKP), Hann Suchocka (OKP), Anna Szymańska-Kwiatkowska (PZPR), Janusz Szymański (PZPR), Janusz Trzciński (PZPR), Sławomir Wiatr (PZPR), Wiesław Woda (PSL - Odrodzenie), Andrzej Zawiślak (OKP), Andrzej Zieliński (PZPR) oraz Ryszard Zieliński (PZPR).

2 I K. 2 uzasadnienia druku nr I 20.

22 Wystąpienie posła Janusza Trzcińskiego - Sprawozdanie stenograficzne z I 4 posiedzenia Sejmu X kadencji z dnia 30 listopada I989 roku, ł. 25-26. 
nie uległa osoba suwerena, którym stał się Naród, sprawującym władze przez swych przedstawicieli wybieranych do Sejmu i Senatu i do rad narodowych. Założono przy tym, że sprawowanie władzy następuje także w formie referendum. Podkreślono przy tym szczególną rolę Sejmu, który miał być najwyższym wyrazicielem woli Narodu oraz miał za zadanie urzeczywistniać jego suwerenne prawa.

Ponadto, co jest nowym rozwiązaniem w stosunku do proponowanych wcześniej zmian, wprowadzono zapis, że „Rzeczypospolita Polska jest demokratycznym państwem prawa, urzeczywistniającym zasady sprawiedliwości społecznej”. Poza tym proponowano wprowadzić zapis, że ,,przestrzeganie praw Rzeczypospolitej Polskiej jest podstawowym obowiązkiem każdego organu państwa” jak też ,,wszelkie organy władzy i administracji państwowej działają na podstawie przepisów prawa”. Co istotne, w uzasadnieniu projektu nie wyjaśniono, co cechuje demokratyczne państwo prawa oraz na czym polega zasada sprawiedliwości społecznej, jedynie lakonicznie stwierdzano, że

w miejsce dotychczasowych treści norm regulujących ustrój polityczny i gospodarczy wprowadza się w projekcie ustrojowe zasady statuujące państwo demokratyczne i państwo prawa, urzeczywistniające zasady sprawiedliwości społecznej ${ }^{23}$.

Inną bardzo istotną zmianą była wprowadzona do ustawy zasadniczej regulacja dotycząca możliwości tworzenia partii politycznych i opierająca się na czterech zasadach:

I. swobody tworzenia partii politycznych,

2. dobrowolności zrzeszania się obywateli w partiach politycznych,

3. pluralizmu politycznego,

4. orzekania o sprzeczności celów lub działalności partii z Konstytucją przez Trybunał Konstytucyjny ${ }^{24}$.

23 Wystąpienie posła Janusza Trzcińskiego - Sprawozdanie stenograficzne z I 4 posiedzenia Sejmu X kadencji z dnia 30 listopada I989 roku, ł. 25-26.

24 Wystąpienie posła Janusza Trzcińskiego - Sprawozdanie stenograficzne z I 4 posiedzenia Sejmu X kadencji z dnia 30 listopada I989 roku, ł. 25-26. 
Kolejny punkt dotyczył aktywności samorządowej oraz gospodarczej obywateli. W znowelizowanych art. 5-7 Konstytucji wprowadzono zapisy, że Rzeczpospolita Polska popiera wszelkie formy samorządności obywateli, gwarantuje swobodę działalności gospodarczej bez względu na formę własności (zakładając przy tym, że ograniczenie tej swobody może nastąpić jedynie w ustawie) oraz poręcza ochronę własności oraz prawo dziedziczenia. W ocenie autorów projektu ,zmiany systemu gospodarczego czynią również konieczną rezygnację z planowania gospodarczego jako instrumentu kierowania przez państwo gospodarką narodową" ${ }^{25}$. Ponadto w ostatnim punkcie wskazano, że wywłaszczenie jest dopuszczalne wyłącznie na cele publiczne i za słusznym odszkodowaniem. Oprócz tego w przypadku części dotyczącej kwestii gospodarczej uchylono zwroty dotyczące narodowego planu społeczno-gospodarczego. Z kolei w przypadku wymiaru sprawiedliwości zawarto jedynie zapis, że ,,wymiar sprawiedliwości w Rzeczypospolitej Polskiej sprawują: Sąd Najwyższy, sądy powszechne i sądy szczególne”. W tym punkcie na szczególną uwagę zasługuje zwrot „sądy powszechne”, którym zastąpiono wyrazy „sądy wojewódzkie” oraz „rejonowe”. Przyjęcie takiego terminu miało także umożliwić dalsze prace legislacyjne w zakresie wymiaru sprawiedliwości.

Bardzo ważnym punktem była regulacja dotycząca prokuratury. W myśl znowelizowanego art. 64, proponowano: ,,prokuratura strzeże praworządności oraz czuwa nad ściganiem przestępstw”. Przy czym miała ona podlegać Ministrowi Sprawiedliwości, będącego zarazem Prokuratorem Generalnym. W tym przypadku, w uzasadnieniu zwrócono uwagę, że podporządkowanie prokuratury Ministrowi Sprawiedliwości spowoduje, że będzie miał on możliwość oddziaływania legalnymi środkami na orzecznictwo sądowe ${ }^{26}$. Na marginesie należy dodać,

25 Wystąpienie posła Janusza Trzcińskiego - Sprawozdanie stenograficzne z I 4 posiedzenia Sejmu X kadencji z dnia 30 listopada I989 roku, ł. 25-26.

26 Wystąpienie posła Janusza Trzcińskiego - Sprawozdanie stenograficzne z I 4 posiedzenia Sejmu X kadencji z dnia 30 listopada I989 roku, ł. 25-26. 
że w przepisach przejściowych przewidziano rozwiązanie, w myśl którego w obrocie prawnym zostaną zachowane druki, formularze oraz blankiety, do momentu ich wyczerpania, z oznaczeniem „Polska Rzeczypospolita Ludowa”. Aczkolwiek pieczęci z takim oznaczeniem Państwa mogbyły być emitowane do dnia 3I grudnia 1995 roku. Również pieczęcie mogły być używane w tym samym terminie.

Powyższy dokument został jeszcze zmodyfikowany przez Komisję Konstytucyjną i w nieco zmienionym kształcie przedstawiony pod obrady sejmowe. Zmodyfikowano zasadę, że „,Rzeczypospolita Polska jest demokratycznym państwem prawa, urzeczywistniającym zasady sprawiedliwości społecznej”, wprowadzając zwrot, że „Rzeczypospolita Polska jest demokratycznym państwem prawnym, urzeczywistniającym zasady sprawiedliwości społecznej". Wprowadzono dwa nowe zapisy o treści: ,,Siły zbrojne Rzeczypospolitej Polskiej stoją na straży suwerenności i niepodległości Narodu Polskiego, jego bezpieczeństwa i pokoju” oraz „Godłem Rzeczypospolitej Polskiej jest wizerunek orła białego w koronie w czerwonym polu". Zmodyfikowano także przepisy przejściowe, że prokuratura najdłużej do dnia 3I marca 1990 roku działa na dotychczasowych zasadach. Druki, formularze z dotychczasową nazwą miały być używane do mementu ich wyczerpania, ale nie później niż do 3I grudnia 1995 roku, tablice urzędowe z dotychczasową nazwą państwa lub też godłem mogły być używane do 3I grudnia I992 roku, a znaki sił zbrojnych mogły być używane nie dłużej niż do 3I grudnia 1995 roku.

\section{Zasada demokratycznego państwa oprawnego w dyskursie sejmowym}

Przedstawione wówczas projekty legislacyjne, wskutek przyjęcia tzw. noweli grudniowej w 1989 roku, ugruntowały pozycję zasady demokratycznego państwa prawnego. Wokół niej jak i przyjętych rozwiązań toczył się dalszy dyskurs parlamentarny, w konsekwencji którego doko- 
nano dalszych zmian w obrębie Konstytucji z 1952 roku, jak téz wprowadzono do porządku prawnego tzw. Małą Konstytucję w I992 roku, a w dalszej części, przystąpiono do prac nad nową konstytucją, przyjętą w dniu 2 kwietnia 1997 roku.

Wspomniany powyżej dyskurs w 1989 roku, toczył się w dwóch odsłonach. Pierwszy dotyczył przedstawionych na wstępie projektów poselskich, a drugi - rozwiązań zaproponowanych przez Komisję Konstytucyjną.

Pierwsza odsłona miała miejsce w dniu 30 listopada 1989 roku podczas I4. posiedzenia Sejmu X kadencji i dotyczyła zaprezentowanych powyżej druków nr 27, 27 A i 80. Szczególną uwagę należy zwrócić na jedno z pierwszych wystąpień, na postulaty posła Józefa Bogusza (PZPR), który zaproponował zarówno usunięcie z zapisów konstytucyjnych regulacji dotyczącej przewodniej roli PZPR, jak też wprowadzenie regulacji odnoszącej się ogólnie do możliwości tworzenia partii politycznych. Argumentował to w ten sposób, że wskutek zmian, jakie zaszły w Polsce,

zasady te nie powinny być dłużej podnoszone do rangi zasad konstytucyjnych. Pozycja określonej partii politycznej w systemie politycznym i jej sojusze koalicyjne powinny zależeć przede wszystkim od woli narodu wyrażonej w wyborach ${ }^{27}$.

Szczególną uwagę należy zwrócić na wystąpienie Hanny Suchockiej. W jej ocenie prace nowelizacyjne ówczesnej Konstytucji z I952 roku, nie można traktować jako jej ulepszanie, gdyż ,,powstaje pytanie, czy można ulepszać coś, czego ulepszać się nie da”28, a zasadnym jest uchwalenie nowej ustawy zasadniczej. Ponadto, według poseł OKP, na obecną chwilę

27 Wystąpienia posła Józefa Bogusza - Sprawozdanie stenograficzne z I4 posiedzenia Sejmu X kadencji z dnia 30 listopada I 989 roku, ł. I6.

28 Wystąpienie poseł Hanny Suchockiej - Sprawozdanie stenograficzne z I 4 posiedzenia Sejmu X kadencji z dnia 30 listopada I989 roku, ł. I9. 
nieodzowna jest więc nowelizacja tych przepisów, które stają na przeszkodzie przekształcenia ustroju państwowego w kierunku zgodnym z wolą narodu lub tworzą rozwiązania instytucjonalne, które należy zmienić lub usunąć, albowiem zdenaturalizowały się w rzeczywistości politycznej, ale są jeszcze utrzymywane w rzeczywistości normatywnej ${ }^{29}$.

Z kolei trzecia okoliczność miała dotyczyć rozpoczętych w kwietniu zmian w aparacie państwowym, ,a zmierzających do stworzenia warunków dla zasady trójpodziału władzy”30. Odnosząc się do innych zmian, wskazała także na konieczność wprowadzenia stosownej terminologii, adekwatnej do obecnie proponowanych zmian. Jednakże zaakcentowała przy tym, że

przedłożony przez nas projekt zmian Konstytucji jest programem minimum. Są to zmiany, które uważamy w obecnej sytuacji za niezbędne, a zarazem są to zmiany takie, które nie będą stwarzać wrażenia, że sztucznie ulepszamy tę Konstytucję, czyli że chcemy poprawić twór, który uchwalony w 1952 roku, nosi na sobie piętno najlepszego okresu stalinowskiego ${ }^{31}$.

W podobnym tonie swe stanowisko przedstawił prof. Bronisław Geremek, odnosząc się do Konstytucji z I952 roku jako do tworu, który poprawić się nie da:

dotyczy to rzeczywistości w jej wymiarze politycznym, gospodarczym, społecznym. Dotyczy także tekstu, który był zwierciadłem i matrycą tej rzeczywistości ${ }^{32}$.

29 Wystąpienie poseł Hanny Suchockiej - Sprawozdanie stenograficzne z I 4 posiedzenia Sejmu X kadencji z dnia 30 listopada I989 roku, ł. I9.

30 Wystąpienie poseł Hanny Suchockiej - Sprawozdanie stenograficzne z I 4 posiedzenia Sejmu X kadencji z dnia 30 listopada I989 roku, ł. I9.

3 I Wystąpienie posła Bronisława Geremka - Sprawozdanie stenograficzne z I 4 posiedzenia Sejmu X kadencji z dnia 30 listopada I989 roku, ł. 2 I .

32 Wystąpienie posła Bronisława Geremka - Sprawozdanie stenograficzne z I 4 posiedzenia Sejmu X kadencji z dnia 30 listopada I989 roku, ł. 23. Na marginesie należy dodać, że Bronisław Geremek wskazał na jeszcze jeden bardzo 
W przypadku dyskursu parlamentarnego należy także wskazać na stanowisko przywołanego już Janusza Trzcińskiego, w ocenie którego proponowane zmiany były konsekwencjąmodyfikacji, jakie zostały wprowadzone przez Sejm IX kadencji w kwietniu 1989 roku. W jego ocenie przedstawione zmiany dotyczą dwóch grup:

I. zagadnień związanych z ustrojem politycznym państwa (prezentując przy tym kwestie związane z prawem własności). Należy przy tym wyłączyć kwestie związane z przemodelowaniem ustroju społeczno-gospodarczego,

2. Ograniczony zakres zmian uzasadniający konieczność wszczęcia prac nad nową konstytucją. A to oznacza, że daleko idące poprawki mogą opóźnić przyjęcie nowej ustawy zasadniczej.

Z kolei w przypadku istniejącej ustawy zasadniczej uznał, że ,obecna Konstytucja w coraz mniejszym stopniu spełnia rolę regulatora życia politycznego i społecznego naszego państwa”. Jednocześnie Janusz Trzciński wyraził przekonanie, podobnie jak prof. Geremek, o przyjęciu nowej konstytucji w rocznicę Konstytucji 3 Maja ${ }^{33}$.

Inne spojrzenie na proponowane zmiany postulował Stanisław Rogowski (UChS), wskazując, że powołany rząd Tadeusza Mazowieckiego funkcjonuje sprzecznie z obowiązującymi zapisami konstytucyjnymi, tym samym uzasadnia to konieczność zmian. W konsekwencji doszło do sytuacji, w której

istotny aspekt zmian, jakie winny być przeprowadzone w Polsce odnośnie do przemian demokratycznym, a mianowicie zmianę ordynacji wyborczej oraz reaktywowanie samorządu terytorialnego wraz z przeprowadzeniem wyborów lokalnych. Ponadto dodał, że OKP będzie zmierzał, aby w rocznicę 200- lecia Konstytucji 3 Maja w Polsce obowiązywała już nowa ustawa zasadnicza - Wystąpienie posła Bronisława Geremka - Sprawozdanie stenograficzne z I 4 posiedzenia Sejmu X kadencji z dnia 30 listopada I 989 roku, 1. 24 .

33 Wystąpienie posła Janusza Trzcińskiego - Sprawozdanie stenograficzne z I4 posiedzenia Sejmu X kadencji z dnia 30 listopada 1989 roku, 1. $25-26$. 
(...) prawo nie pokrywa się z rzeczywistością. Formalne istnienie przepisów nie akceptowanych i nie wykonywanych jest zawsze społecznie demoralizujące i obniża rangę prawa w społeczeństwie ${ }^{34}$.

Ponadto uznał, że art. 3 Konstytucji (odnoszący się do szczególnej pozycji PZPR), winien stanowić przestrogę dla innych, którzy chcieliby ująć w ramy prawne aspekty życia politycznego. Nadto tego rodzaju rozwiązania wpływają hamująco na rozwój życia politycznego. Mimo wszystko wysunął przy tym propozycję, aby do zapisów konstytucyjnych wprowadzić zapis zakazujący istnienia organizacji, które wykraczają poza porządek prawny państwa ${ }^{35}$. Jednakże, jak dodał, zmiany konstytucyjne w sferze politycznej winny dotyczyć również zmian w obrębie gospodarki.

Z kolei inny punkt wyjścia w kwestii zmian politycznych zaproponował Stefan Bieliński (Stronnictwo Demokratyczne). O ile wcześniejsze propozycje dotyczyły wykreślenia regulacji odnoszącej się do przewodniej roli PZPR, tak w tym przypadku proponowany punkt wyjścia, do dalszych przemian demokratycznych, miał dotyczyć zmiany nazwy państwa i zmiany godła. Zmiana nazwy państwa jak i godła oznaczałaby początek

tworzenia demokracji parlamentarnej. Moment ten byłby początkiem tworzenia Rzeczypospolitej, tzn. demokracji parlamentarnej o wielopartyjnym systemie Rzeczypospolitej jako państwa o ustroju demokratycznym, w którym władza pochodzi z wyboru ${ }^{36}$.

34 Wystąpienie posła Stanisława Rogowskiego - Sprawozdanie stenograficzne z I4 posiedzenia Sejmu X kadencji z dnia 30 listopada I989 roku, ł. 34.

35 Wystąpienie posła Stanisława Rogowskiego - Sprawozdanie stenograficzne z I4 posiedzenia Sejmu X kadencji z dnia 30 listopada I989 roku, ł. 35. Przedstawione przez niego uwagi dotyczyły poselskiego projektu zmiany Konstytucji zawartego w druku nr 25.

36 Wystąpienie posła Stefana Bilińskiego - Sprawozdanie stenograficzne z I 4 posiedzenia Sejmu X kadencji z dnia 30 listopada I989 roku, ł. 36. 
Kolejny postulat, wśród proponowanych przez niego zmian, dotyczył modyfikacji godła na orła w koronie. Argumentował: ,,przywrocenie tego symbolu niech stanie się znakiem procesu destalinizacji i suwerenności narodu" ${ }^{37}$.

Odrębną uwagę należy zwrócić na indywidualne wystąpienie posła PZPR - Marcina Czerwińskiego, będącego wezwaniem skierowanym do członków klubu parlamentarnego PZPR, aby poparli proponowane zmiany, które wprowadzają w ,,przedsionek demokracji” ${ }^{38}$.

Mimo iż cały dyskurs toczył się wokół modyfikacji w obrębie ustawy zasadniczej, uwadze uszła inna część ustawy, jaką jest preambuła. $\mathrm{Na}$ tą kwestię wskazał przedstawiciel OKP - Andrzej Kern. Uznał wówczas, że preambuła winna zostać zmieniona z trzech głównych powodów. Po pierwsze, w jego ocenie, była pisana językiem epoki, która już odeszła (albo odchodzi), po drugie zawierała tezy będące kłamstwami. Do takich założeń, według Kerna, należało zaliczyć sformułowanie, że ,,wciela się w życie wiekopomne wskazania Manifestu Polskiego Komitetu Wyzwolenia Narodowego z 22 lipca I944 roku i rozwija jego zasady programowe". W tym punkcie Kern ironicznie stwierdził:

gdyby nie odstąpiono od zasad demokratycznych zwartych w Manifeście Polskiego Komitetu Wyzwolenia Narodowego, bylibyśmy dzisiaj innym państwem, państwem o zupełnie innym kształcie ${ }^{39}$.

Z kolei trzecia kwestia miała dotyczyć filozofii sprawowania władzy, jaka została ujęta w preambule Konstytucji. Dotyczyła ona sojuszu robotniczo-chłopskiego. Z kolei w systemie demokratycznym ,nie ma

37 Wystąpienie posła Stefana Bilińskiego - Sprawozdanie stenograficzne z I 4 posiedzenia Sejmu X kadencji z dnia 30 listopada I 989 roku, ł. 37.

38 Wystąpienie posła Marcina Czerwińskiego - Sprawozdanie stenograficzne z I4 posiedzenia Sejmu X kadencji z dnia 30 listopada I989 roku, ł. 39 .

39 Wystąpienie posła Andrzeja Kerna - Sprawozdanie stenograficzne z I 4 posiedzenia Sejmu X kadencji z dnia 30 listopada I 989 roku, ł. 40 . 
takiej partii, takiej organizacji i takiej klasy społecznej, która miałby monopol na tworzenie ustroju sprawiedliwości społecznej (...)"40.

Najważniejsza debata sejmowa, odnosząca się do zasady demokratycznego państwa prawnego, odbyła się w dniu 29 grudnia 1989 roku. $\mathrm{Na}$ wstępie należy już zaakcentować szczególną pozycję poseł OKP Hanny Suchockiej, która była sprawozdawcą prac Komisji. Przedstawione wcześniej projekty zmian w obrębie Konstytucji, jak się potem okaże, oscylujące wokół zasady demokratycznego państwa prawnego, stanowiły podstawę do opracowania projektu zmian przez Komisję Konstytucyjną. Dyskurs legislacyjny, jaki miał miejsce w dniu 29 grudnia 1989 roku, był dyskursem wielowątkowym i burzliwym, aczkolwiek pozytywnie oceniającym proponowane zmiany. Głównymi punktami, jakie przyświecały pracom komisji, w ocenie Suchockiej, było wprowadzenie takich rozwiązań,

które mają prawnie usankcjonować istniejący już stan polityczny, a zatem doprowadzić do zgodności rzeczywistość normatywną z rzeczywistością polityczno-społeczną̨ ${ }^{4+}$.

Problematyczny był termin wprowadzenia nowej nazwy państwa. W tym punkcie powstało pytanie: czy nazwę wprowadzić już teraz, czy też czekać na nową konstytucję. W przypadku gdyby ta nowa nazwa była wprowadzona pod rządami Konstytucji z 1952 roku, to oznaczałoby, że za cel legislacyjny przyjęto ulepszanie tego aktu prawnego, a to nie było zadaniem Komisji. Aczkolwiek Suchocka w swej prezentacji zmian była świadoma, że wprowadzone modyfikacje nie będą spójne. Jednakże spójność Konstytucji zostanie zagwarantowana w momencie przyjęcia nowej ustawy zasadniczej. W konsekwencji miało to również oznaczać odstąpienie komisji od prac nad innymi

40 Wystąpienie posła Andrzeja Kerna - Sprawozdanie stenograficzne z I 4 posiedzenia Sejmu X kadencji z dnia 30 listopada I989 roku, ł. 40.

4I Wystąpienie poseł Hanny Suchockiej - Sprawozdanie stenograficzne z I7 posiedzenia Sejmu X kadencji z dnia 29 grudnia I 989 roku, ł. 220. 
częściami Konstytucji, które nie były ujęte w przedstawionych wcześniej projektach poselskich, jak np. prawa i obowiązki obywatela ${ }^{42}$.

Wspomniany dyskurs oscylował wokół pozycji prokuratury w znowelizowanej konstytucji, poszanowania prawa własności, zmiany nazwy państwa, uśnięcia preambuły czy też wprowadzenia nowego godła. Szczególną uwagę należy zwrócić na ocenę zasady demokratycznego państwa prawnego, przedstawioną przez Tadeusza Bienia (z treści jego wystąpienia wynika, że działającego także w imieniu posła Andrzeja Kerna). W jego ocenie znowelizowany art. I winien brzmieć: „,Rzeczpospolita Polska jest demokratycznym państwem wolnych obywateli, urzeczywistniającym zasady prawa i sprawiedliwości społecznej”. Uznał przy tym, że nawet i ten proponowany zwrot jest niezrozumiały: ,,najważniejszy jest człowiek, jest podmiotem państwa, a nie samo prawo. Prawo jest tworzone dla ludzi. Dlatego sformułowanie "państwo wolnych obywateli» winno być na początku"

$\mathrm{Na}$ ten temat wypowiedziała się Hanna Suchocka, wskazując na dokonaną zmianę, którą przeprowadziła Komisja Konstytucyjna. Zwrot „,demokratyczne państwo prawa” zostało zastąpione terminem ,,demokratyczne państwo prawne" ${ }^{4}$. Stwierdziła przy tym, że

sformułowanie ,demokratyczne państwo prawne” ma określoną treść w teorii państwa i prawa, natomiast ,demokratyczne państwo prawa” byłoby pojęciem nowym, które wymagałoby, być może, różnych interpretacji i wywoływałoby pewne wątpliwości, jaki jest zakres różnic między państwem prawa a państwem prawnym. Podtrzymaliśmy zatem generalną formułę, zmieniając ją tylko na przymiotnikową ${ }^{45}$.

42 Wystąpienie poseł Hanny Suchockiej - Sprawozdanie stenograficzne z I7 posiedzenia Sejmu X kadencji z dnia 29 grudnia I989 roku, 1. 223.

43 Wystąpienie posła Tadeusza Bienia - Sprawozdanie stenograficzne z I7 posiedzenia Sejmu X kadencji z dnia 29 grudnia I989 roku, ł. 308.

44 Wystąpienie poseł Hanny Suchockiej - Sprawozdanie stenograficzne z I7 posiedzenia Sejmu X kadencji z dnia 29 grudnia I989 roku, ł. 272.

45 Wystąpienie poseł Hanny Suchockiej - Sprawozdanie stenograficzne z I7 posiedzenia Sejmu X kadencji z dnia 29 grudnia I 989 roku, ł. 272. 
Ponadto Suchocka wskazała, że odstąpiono od tego, aby w znowelizowanej Konstytucji odstąpić od ujęcia terminu, że Polska jest „państwem wolnych obywateli”, gdyż termin ,,demokratyczne państwo prawne” zawiera w sobie powyższe sformułowanie, a nawet ,,zawiera koncepcję poszerzenia niejako zakresu wolności” ${ }^{46}$.

\section{Zakończenie}

Przyjęta w dniu 29 grudnia 1989 roku, tzw. nowela grudniowa zamknęła pewien rozdział historii. Procesy społęczno-polityczne, jakie dokonały się zwłaszcza w 1989 roku, znalazły swe usankcjonowanie w ustawie zasadniczej. W tym punkcie można dodać, że owa nowela stanowiła dopiero początek zmian, jakie miały się dokonać w polskim systemie prawnym, a polegały na stworzeniu regulacji prawnych dotyczących systemu gospodarczego i gospodarki wolnorynkowej. Odnośnie do przedstawionych zmian w procesie wprowadzenia zasady demokratycznego państwa prawnego oraz podstaw ustroju demokratycznego należy odnotować dwie kwestie. Po pierwsze udział wszystkich ugrupowań politycznych, jakie zasiadały w Sejmie X kadencji, które zgodne były w przedmiocie podjęcia zmian w obrębie Konstytucji z I952 roku, jak i deklarowały konieczność wprowadzenia nowej ustawy zasadniczej (przypominając, że miała być pierwotnie wprowadzona w rocznicę Konstytucji 3 Maja, czyli w I99I roku). Kolejna kwestia dotyczy aktywności posłów wywodzących się z PZPR, którzy nie tyle tamowali proces legislacyjny, co równie aktywnie w nim uczestniczyli. Proces zmian zaszedł już tak daleko, że w zasadzie nie było możliwe jego zatrzymanie. Ponadto wydarzenia, jakie miały miejsce w innych krajach Europy Środkowo-Wschodniej wskazywały, że epoka komunizmu w tej części globu powoli zmierza do przeszłości.

46 Wystąpienie poseł Hanny Suchockiej - Sprawozdanie stenograficzne z I7 posiedzenia Sejmu X kadencji z dnia 29 grudnia I989 roku, ł. 272. 
Reasumując analizę niniejszego artykułu należy przytoczyć wypowiedź ówczesnego marszałka Sejmu - prof. Mikołaja Kozakiewicza, który kończąc posiedzenie w dniu 29 grudnia 1989 roku, stwierdzit:

ustawy, które Sejm wczoraj i dzisiaj zatwierdził, zmieniają wszak system społeczno-ekonomiczny kraju. Polska, która stanie się w wyniku tych ustaw, będzie całkowicie inną Polską. Musimy zdawać sobie z tego sprawę. Stało się dzisiaj coś przełomowego ${ }^{47}$.

\section{Streszczenie}

DEMOKRATYCZNE PAŃSTWO PRAWNE I PODSTAWY USTROJU DEMOKRATYCZNEGO W DYSKURSIE SEJMU X KADENCJI

Wybory czerwcowe w 1989 roku, w wyniku których doszło do wprowadzenia do polskiego parlamentu przedstawicieli ówczesnych środowisk opozycyjnych, diametralnie zmieniły sejmowy dyskurs polityczno-prawny. W wyniku tzw. noweli grudniowej z 29 grudnia 1989 rokutj. nowelizacji Konstytucji PRL z 22 lipca 1952 roku do ówczesnej ustawy zasadniczej została wprowadzona tzw. zasada demokratycznego państwa prawnego, przy jednoczesnym odrzuceniu zapisów dotyczących przewodniej roli partii komunistycznej jak też sojuszowi z ZSRR. Niewątpliwie zmiany z drugiej połowy 1989 roku stanowiły kontynuację zmian z pierwszej połowy 1989 roku, której wówczas owocem była tzw. nowela kwietniowa. Co istotne, w przypadku pierwszej połowy I989 roku inicjatorem zmian były ustalenia podjęte podczas obrad Okrą̧łego Stołu, a projekty zmian w obrębie konstytucji zostały opracowane przez Radę Państwa. Natomiast w drugiej połowie 1989 roku (czyli po tzw. wyborach czerwcowych) zanim doszło do debaty na

47 Wystąpienie Marszałka Sejmu Mikołaja Kozakiewicza - Sprawozdanie stenograficzne z I 7 posiedzenia Sejmu X kadencji z dnia 29 grudnia I989 roku, ł. 3 I 2 . 
forum Sejmu, a później na forum Senatu, propozycje zmian konstytucyjnych zostały przedstawione w drukach sejmowych, stanowiących przedmiot inicjatywy poselskiej. Przedmiotem niniejszej pracy jest przybliżenie najważniejszych dokumentów sejmowych zawierających ówczesne postulaty odnoszące się do radyklanych zmian w obrębie konstytucji. Szczególną uwagę należy poświęcić kwestii zasady demokratycznego państwa prawa, stanowiącej fundament nowego ustroju polityczno-prawnego.

\section{Summary}

DEMOCRATIC RULE OF LAW AND THE FOUNDATIONS OF THE DEMOCRATIC SYSTEM IN THE DISCOURSE OF THE SEJM OF THE 1OTH TERM

The June elections in 1989, as a result of which representatives of the then contemporary opposition circles were introduced to the Polish parliament, radically changed the Sejm's political and legal discourse. As a consequence of the December Novelization of December 29, 1989, that is the amendment to the Constitution of the Polish People's Republic of July 22, 1952, the principle of a democratic state ruled by law came into force rejecting the provisions on the leading role of the communist party as well as the alliance with the USSR. Undoubtedly, the changes of the second half of 1989 were a continuation of the changes of the first half of 1989 , which then resulted in the so-called April Novelization. Importantly, in the first half of 1989, the arrangements made during the Round Table negotiations initiated the transition, and draft amendments to the constitution were developed by the Council of State. In turn, in the second half of 1989 (i.e. after the so-called June elections), before the debate in the Sejm forum and later in the Senate forum took place, proposals for constitutional changes were presented in parliamentary texts, which were the subject of a parliamentary initiative. The aim of this thesis is to 
present the most important Sejm documents containing the then postulates relating to radical changes within the constitution. Particular attention should be paid to the issue of the principle of a democratic rule of law underpinning the new political and legal system.

\section{Bibliografia}

Sprawozdania stenograficzne z Sejmu X kadencji z 1989 r.

Druk nr 25 z dnia 6 września 1989 r.

Druk nr 26 z dnia 6 września $1989 \mathrm{r}$.

Druk nr 27 z dnia 23 sierpnia $1989 \mathrm{r}$.

Druk nr 27A z dnia 7 września 1989 r.

Druk nr 35 z dnia I3 września I989 r.

Druk nr 80A z dnia 29 listopada $1989 \mathrm{r}$.

Druk nr IO3 z dnia 29 listopada $1989 \mathrm{r}$. 
A. Uniwersytet Papieski

过, Jana Pawła II

(b w Krakowie 